\title{
Zinc Finger Protein 521
}

National Cancer Institute

\section{Source}

National Cancer Institute. Zinc Finger Protein 521. NCI Thesaurus. Code C97887.

Zinc finger protein 521 (1311 aa, $148 \mathrm{kDa}$ ) is encoded by the human ZNF521 gene. This protein plays a role in the modulation of transcription. 